\title{
Impacts of Financial Stock Prices and Exchange Rates on the Demand for Money in Poland
}

\section{Yu Hsing}

\section{Abstract}

Applying the extended Box-Cox model and the Newey-West method, this paper finds that the demand for real M2 is positively influenced by real GDP and the real effective exchange rate, negatively affected by the deposit rate and the world interest rate, and not correlated with the real financial stock price. Hence, real depreciation of the zloty or a lower world interest rate would raise real output. The widely used log-linear form or the linear form can be rejected at the $5 \%$ or $1 \%$ level in favor of the extended Box-Cox model, suggesting that the elasticity or the slope is not a constant but varies with the values of the dependent and independent variables.

DOI: $10.2478 / \mathrm{v} 10033-007-0010-4$

\section{Introduction}

Since its transition to a market economy, the quantity of money in Poland has increased in the long run with some fluctuations in the short run partly due to economic growth. Real M2 declined from 207,847 million zlotys in 1990 to 161,125 million zlotys in 1991. An analysis of macroeconomic variables suggests that the decline in real M2 may be associated with a decrease in real GDP from 276,213 million zlotys to 256,954 million zlotys, an increase in the deposit rate from $41.67 \%$ to $53.50 \%$, and/or an increase in the zloty/USD exchange rate from 0.95 to 1.06 during the same period. Real M2 rose from 189,800 million zlotys in 1995 to 207,472 million zlotys in 1996. The increase may be attributable to an increase in real GDP from 337,222 million zlotys to 358,261 million zlotys, a decrease in the deposit rate from $26.78 \%$ to $20.02 \%$, and/or real appreciation of the zloty during the same period. It is surprising to observe the decline in real M2 from 306433 million zlotys in 2001 to 321173 million zlotys in 2002 in view of an increase in real GDP, a decrease in the deposit rate, and real depreciation of the zloty.

The demand for money is an important macroeconomic foundation. The interaction between money demand and money supply determines the money market equilibrium.
While monetary policy is determined by the European Central Bank (ECB) since Poland joined the EU in May 2004, unique relationships may exist between money demand and its determinants in Poland. The sensitivity of money demand to a change in one of the explanatory variables may vary among EU member countries

This paper examines the demand for money for Poland with several focuses. First, the paper will discuss the interaction between the money market equilibrium and the goods market equilibrium and the impact of a change in one of the explanatory variables in money demand on the equilibrium output. Second, the extended Box-Cox model (Box-Cox, 1964; Seaks and Layson, 1983; Hsing and Chang, 2003; Hsing, 2006) is applied in empirical work to determine whether the widely used log-linear form or the linear form would be appropriate. Many previous studies chose the log-linear form a priori partly

\section{*Hsing: Charles Blackwell Endowed Professor of Economics}

Department of General Business - SLU 10813

College of Business Southeastern Louisiana University

Hammond, Louisiana 70402 USA.

e-mail: yhsing@selu.edu 
because the log-linear form exhibits a constant elasticity of money demand. Third, the Newey-West (1987) method will be employed in empirical work to yield consistent covariance and standard errors when the forms of heteroskedasticity and autocorrelation are unknown.

There are several recent studies of money demand for Poland and/or its neighboring countries. Van Aarle and Budina (1996) showed that there was evidence of currency substitution for Poland, Hungary, Bulgaria, and Romania. Buch (2001) examined the money demand functions for Poland and Hungary and found that in several specifications, money demand and other variables are cointegrated and that estimated money demand functions can serve as useful tools for the central banks. Rusek (2001) indicated that a stable money demand function for Poland and the other three East European countries could not be estimated and that there was a lack of equilibrium relationships among the nominal variables in money demand. Kruszka (2003) studied the demand for cash for four Eastern European countries during 1994-2003 and showed that variables in the demand for money for Poland were I(1) and had at least one cointegrating relationship, that the income elasticity was estimated to be 0.997 , and that the coefficients of the nominal interest rate and the inflation rate had wrong signs. Reimers (2004) conducted large-scale research on the long-run money demand function for eleven Eastern European countries based on a sample from 1993 to 2001. He found that for Poland, the coefficients estimated by the FM-OLS and two-step method for real income, the interest rate and the inflation rate were 2.91, -0.03 , and 3.90, respectively and that large differences were found across countries. Dreger and Reimers (2005) examined the money demand function for ten Eastern European countries during 1995-2004 and revealed that real broad money demand in general had a positive relationship with real income and the euro exchange rate and a negative relationship with the domestic interest rate and the U.S. dollar exchange rate.

\section{The Model}

Suppose that the demand for money in Poland is determined by real output, the domestic interest rate, the real financial stock price, the real exchange rate, and the world interest rate and can be expressed as

$$
\begin{aligned}
& M=L\left(Y, R, W, E, R^{*}\right) \\
& L_{Y}>0, L_{R}<0, L_{W}>\boldsymbol{D}<0, L_{E}>\boldsymbol{D}<0, L_{R^{*}}>\boldsymbol{D}<0
\end{aligned}
$$

where:

$M=$ demand for real money balances,

$Y=$ real output

$\mathrm{R}=$ the domestic interest rate,

$W=$ the real stock price,

$E=$ the real effective exchange rate, and

$\mathrm{R}^{*}=$ the world interest rate.

The demand for money is expected to have a positive relationship with real output and a negative relationship with the domestic interest rate. An increase in the real stock price may reduce or increase the demand for money due to the substitution effect or the wealth effect (Friedman, 1988; Fase and Winder, 1998). Real appreciation of the zloty may increase or reduce the demand for money due to the substitution effect or the wealth effect (Arango and Nadiri, 1981; McKinnon, 1982; Bahmani-Oskooee and Techaratanachai, 2001; BahmaniOskooee and Ng, 2002). A higher world interest rate may reduce or increase the demand for money because of the capital mobility effect or the cost of borrowing effect (Marquez, 1987; Bahmani-Oskooee and Ng, 2002).

The signs of the partial derivative of the demand for money with respect to the real stock price, the real effective exchange rate, and the world interest rate in equation (1) are crucial because they may influence the equilibrium real output differently. Suppose that the goods market equilibrium is given by

$$
Y=H\left(Y, R-\mathrm{p}^{e}, G, T, W, E\right)
$$

where

$\mathrm{H}=$ = aggregate spending,

$\pi^{\mathrm{e}}=$ the expected inflation rate,

G = government spending, and

$\mathrm{T} \quad=$ government tax revenues 
The impact of a change in the real stock price, the real effective exchange rate, or the world interest rate on the equilibrium output can be expressed as

$\partial \bar{Y} / \partial W=\left(-H_{W} L_{R}+H_{R} L_{W}\right) /|J|>0 f \quad L_{W}<0$ and $>\boldsymbol{0}<0 f L_{W}>0$

$\partial \bar{Y} / \partial E=\left(-H_{E} L_{R}+H_{R} L_{E}\right) /|J|<0 f L_{E}>0$ and $>0$ ø $<0 f L_{E}<0$

$\partial \bar{Y} / \partial R^{*}=H_{R} L_{R^{*}} /|J|>0 f L_{R^{*}}<0$ and $<0 f L_{R^{*}}>0$

where $H_{x}$ is the partial derivative of aggregate spending with respect to any exogenous variable $X$ and $I J$ is the Jacobian of the endogenous variables with a positive value. As shown, the sign of $L_{w^{\prime}} L_{E}$ and $L_{r}$ crucial in determining whether a change in one of the variables would affect the equilibrium real output positively or negatively. The equilibrium real GDP is expected to increase if the demand for money responds to the real stock price or the world interest rate negatively and to decline if the demand for money responds to the real appreciation of the zloty positively.

The extended Box-Cox model is employed to transform all the variables with positive values as follows

$$
\begin{aligned}
& M^{(1)}=\left(M^{1}-1\right) / I, \\
& X^{(1)}=\left(X^{1}-1\right) / I,
\end{aligned}
$$

where $X$ is any of the right-hand-side variables and $\lambda$ is the transformation parameter. It can be shown that when $\lambda$ approaches zero, equation (1) reduces to a log-linear form, and when $\lambda=1$, equation (1) becomes a linear form. The test statistic has a $\chi^{2}$ distribution with one degree of freedom and is given by

$$
2\left[\ln L(\hat{\mid})-\mathrm{h} L(\mathrm{I}=0 \boldsymbol{D} 1] \sim \chi_{(1)}^{2}\right.
$$

\section{Empirical Results}

The data source came from the International Financial Statistics published by the International Monetary Fund. Real M2 is chosen as the monetary aggregate because it contains saving or money market deposits, small time deposits, and money market mutual funds and is regarded as a broader measure of money. Real M2 is equal to nominal M2 divided by the CPI and measured in million zlotys. Real GDP is measured in million zlotys at the 2000 price. The deposit rate is selected to represent the domestic interest rate. The real effective exchange rate is an index number with $2000=100$. An increase in the real effective exchange rate means real appreciation of the zloty, and vice

\begin{tabular}{|c|c|c|c|}
\hline Real effective Exchange Rate & $\begin{array}{c}\text { Box-Cox } \\
\text { Regression }\end{array}$ & $\begin{array}{l}\text { Log-Linear } \\
\text { Regression }\end{array}$ & $\begin{array}{c}\text { Linear } \\
\text { Regression }\end{array}$ \\
\hline Real Output & $\begin{array}{c}0.894 \\
(4.370)\end{array}$ & $\begin{array}{c}0.682 \\
(5.210)\end{array}$ & $\begin{array}{c}0.706 \\
(5.468)\end{array}$ \\
\hline Deposit Rate & $\begin{array}{c}-1.69 E+08 \\
(-13.530)\end{array}$ & $\begin{array}{c}-0.066 \\
(-2.184)\end{array}$ & $\begin{array}{c}-3268.972 \\
(-6.066)\end{array}$ \\
\hline Real Stock Price & $\begin{array}{c}9.325 \\
(1.290)\end{array}$ & $\begin{array}{c}-0.114 \\
(-2.117)\end{array}$ & $\begin{array}{c}-0.706 \\
(-1.315)\end{array}$ \\
\hline $\begin{array}{l}\text { Real effective } \\
\text { Exchange Rate }\end{array}$ & $\begin{array}{c}5849468 \\
(7.452)\end{array}$ & $\begin{array}{c}0.578 \\
(4.676)\end{array}$ & $\begin{array}{c}1457.048 \\
(7.531)\end{array}$ \\
\hline Euro Interest Rate & $\begin{array}{c}-3.50 E+08 \\
(-2.405)\end{array}$ & $\begin{array}{c}-0.217 \\
(-2.734)\end{array}$ & $\begin{array}{c}-7342.920 \\
(-3.073)\end{array}$ \\
\hline Constant & $\begin{array}{c}3.19 E+10 \\
(2.813)\end{array}$ & $\begin{array}{c}3.128 \\
(1.494)\end{array}$ & $\begin{array}{c}90074.060 \\
(2.108)\end{array}$ \\
\hline $\mathrm{R}^{2}$ & 0.970 & 0.927 & 0.955 \\
\hline D-W Statistic & 1.629 & 0.935 & 1.022 \\
\hline$\lambda$ & 2.06 & 0.000 & 1.000 \\
\hline Log Likelihood & -395.569 & -416.284 & -404.423 \\
\hline \multirow[t]{2}{*}{ Test statistic } & & 39.430 & 17.708 \\
\hline & 2.346 & 4.199 & 2.912 \\
\hline Theil Inequality Coef. & 0.014 & 0.026 & 0.018 \\
\hline
\end{tabular}
versa. The euro government bond rate is chosen to represent the world interest rate. The sample runs from 1996.Q1 to 2005.Q2.

The Newey-West method is employed to estimate standard errors and covariance.

Figures in the parenthesis are t-ratios.

$* * *, * *, *$ denote $1 \%, 5 \%$, and $10 \%$ significance levels.

MAPE is the mean absolute percent error.

Table 1.

Estimated Regressions of the Demand for Money in Poland: 1996.Q1-2005.Q2

The ADF unit root test is performed first. The critical value is -3.62 at the $1 \%$ level and -2.94 at the $5 \%$ level. All the variables in levels have unit roots and all the variables in first difference are stationary at the $5 \%$ or $1 \%$ level. The Johansen 

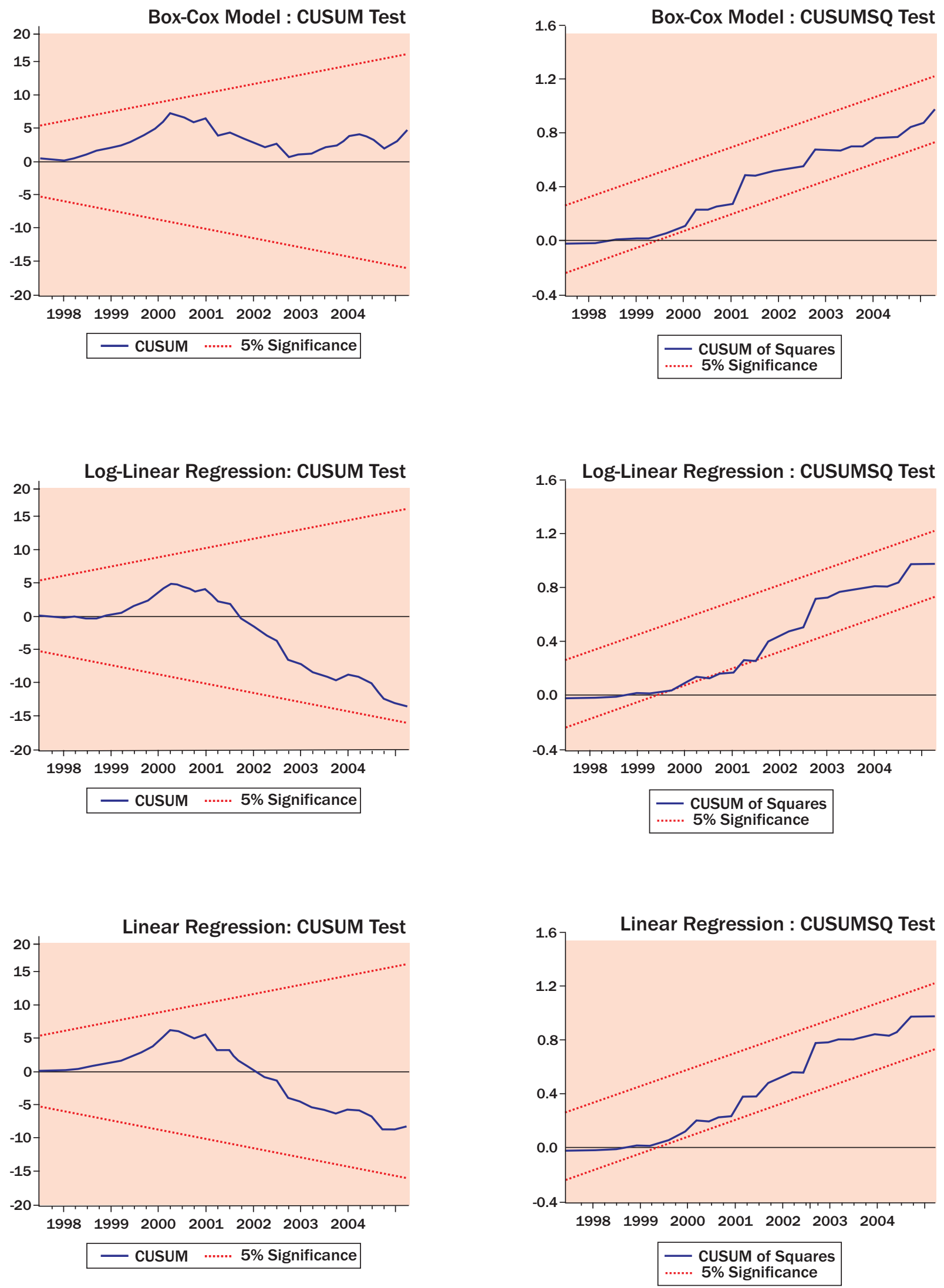

Graph 1

Stability Tests 
cointegration test shows that there are 3 cointegrating relationships at the $5 \%$ level when the trace test is applied.

The functional form is tested next. The value of $L(\lambda)$ is -395.569 with an estimated $\lambda$ of 2.06 . The value of $L(\lambda=0)$ for the log-linear form is -416.284 . The test statistic of 39.430 is far greater than the critical value of 6.635 at the $1 \%$ level. Hence, the log-linear form can be rejected. The value of $L(\lambda=1)$ for the linear form is -404.423 . Comparing the test statistic of 17.708 with the critical value of 6.635 at the $1 \%$ level, the linear form can be rejected at the $1 \%$ level.

Table 1 presents empirical results for the regression based on the extended Box-Cox model, the log-linear regression, and the linear regression. In the Box-Cox regression, the value of $R^{2}$ is 0.970 . Real $M 2$ demand has a positive relationship with real output and the real effective exchange rate and a negative relationship with the deposit rate and the euro interest rate. The coefficient of the real stock price is insignificant at the 10\% level. The mean absolute percent error and the Theil inequality coefficient are estimated to be 2.346 and 0.014 , respectively. The values of the estimated elasticity of money demand at the means with respect to real output, the deposit rate, the real effective exchange rate, and the world interest rate are $0.369,-0.168,0.486$, and -0.203 , respectively.

In the log-linear regression, the value of $R^{2}$ is 0.927 , which is lower than that in the Box-Cox model. Real M2 is positively associated with real output and the real effective exchange rate and negatively affected by the deposit rate, the real stock price, and the euro interest rate. The mean absolute percent error and the Theil inequality coefficient are estimated to be 4.199 and 0.026 , respectively. In the linear regression, the value of $R^{2}$ is 0.955 . The coefficients of real output and the real effective exchange rate are positive and significant, the coefficients of the deposit rate and the euro interest rate are negative and significant, and the coefficient of the real stock price is negative and insignificant. The mean absolute percent error and the Theil inequality coefficient are 2.912 and 0.018 , respectively.

The critical values of the Durbin-Watson test at the $1 \%$ level are $d_{L}=1.019$ and $d_{U}=1.585$, respectively. Compared with the test statistics, the absence of autocorrelation in the Box-Cox regression cannot be rejected whereas the absence of autocorrelation in the log-linear or linear regression can be rejected or is inconclusive. Hence, an incorrect functional form may be one of the reasons for serial correlation.

The CUSUM and CUSUMSQ tests are reported in Graph 1. As shown, the Box-Cox model exhibits better results than the loglinear or linear regression because the cumulative sums of the recursive residuals become larger over time or because part of the cumulative sum of squares in the log-linear regression is outside of the critical lines, suggesting variance instability. If the rejected log-linear regression is chosen, we may draw the misleading conclusion that the demand for real $M 2$ reacts negatively to a change in the real stock price. In comparison, the extended Box-Cox model shows better statistical outcomes in terms of the value of R2, the log likelihood value, the mean absolute percent error, the Theil inequality coefficient, or the stability tests.

Based on empirical results, the coefficient of the real stock price is insignificant, the coefficient of the real effective exchange rate is positive and significant, and the coefficient of the world interest rate is negative and significant. Hence, their respective impacts on the equilibrium output can be shown as follows:

\section{$\partial \bar{Y} / \partial W>0$ because $L_{W}=0$ \\ $\partial \bar{Y} / \partial E<0$ because $L_{E}>0$ $\partial \bar{Y} / \partial R^{*}>0$ because $L_{R^{*}}<0$}

Several different measures of the variables are considered. When the yield on a U.S. 10-year Treasury bond is used as a proxy for the world interest rate, the coefficient is positive and insignificant. It may suggest that the euro interest rate is a better proxy for the world interest rate due to Poland's geographical position in Europe. If the real zloty/USD exchange rate is employed, the coefficient is positive and insignificant at the $10 \%$ level. It suggests that the real effective exchange rate may be a better proxy because it is a trade-weighted measure including major currencies such as the U.S. dollar, the euro, the British pound, etc.

\section{Summary and Conclusions}

The This paper has examined the demand for money in Poland. Explanatory variables include real output, the deposit rate, the real stock price, the real effective exchange rate, and the world interest rate. The study finds that both the log-linear and linear forms can be rejected in favor of the Box-Cox model. The Box-Cox model exhibits a higher value of R2, lack of serial correlation, a lower value of the mean absolute percent error, a lower value of the Theil inequality coefficient, and more parameter stability. In the Box-Cox model, real M2 is positively affected by real output and the real effective exchange rate and negatively associated with the deposit rate and the world interest rate. The coefficient of the real financial stock price is found to be insignificant at the $10 \%$ level. These findings suggest that the substitution effect of the real effective exchange rate is 
greater than the wealth effect, that the capital mobility effect of the world interest rate is greater than the cost of borrowing effect, and that via the money and goods market equilibrium, real depreciation or a higher world interest rate is expected to raise real output.

There are several policy implications. Because the log-linear form can be rejected, the constant elasticity as implied in the log-linear form does not apply to money demand in Poland. Instead, the elasticity of money demand would vary with the transformation parameter, the value of money demand, and the value of the explanatory variable. The insignificance of the real stock price suggests that LM will not shift when the real stock price changes. Hence, a higher real stock price is expected to shift IS upward and raise real output. The positive sign of the coefficient of the real effective exchange rate suggests that real appreciation is expected to hurt real output. Hence, real depreciation may be considered in stimulating exports, reducing imports, and reducing the demand for money.

\section{References}

Arango, S. and M. I. Nadiri (1981), "Demand for Money in Open EBahmani-Oskooee, M. and A. Techaratanachai (2001), "Currency Substitution in Thailand," Journal of Policy Modeling, 23, 141-1.45

Bahmani-Oskooee, M. and S. Chomsisengphet (2002), "Stability of M2 Money Demand Function in Industrial Countries," Applied Economics, 34, 2075-2083.

Bahmani-Oskooee, M. and R. C. W. Ng (2002), "Long-Run Demand for Money in Hong Kong: An Application of the ARDL Model," International Journal of Business and Economics, 1, 147-155.

Bahmani-Oskooee, M. and Rehman, H. (2005), "Stability of the Money Demand Function in Asian Developing Countries," Applied Economics, 37, 773-792.

Box, G. E. P. and D. R. Cox (1964), "An Analysis of Transformation," Journal of Royal Statistical Society, 26, 211-243.

Buch, C. M. (2001). "Money Demand in Hungary and Poland," Applied Economics, 33, 989-999.

Carlson, J. B., D. L. Hoffman, B. D. Keen, and R. H. Rasche (2000), "Results of A Study of the Stability of Cointegrating Relations Comprised of Broad Monetary Aggregate," Journal of Monetary Economics, 46, 345-83.

Chow, G. C. (1966), "On the Long-Run and Short-Run Demand for Money," Journal of Political Economy, 74, 111-31.

Dreger, C. and H.-E. Reimers (2005), "Long-Run Money Demand in the New EU Member States with Exchange Rate Effects," conference paper, 1-22.

Duca, J. V. (2000), "Financial Technology Shocks and the Case of the Missing M2," Journal of Money, Credit, and Banking, 32, Part 1, 820-39.

Fase, M. M. G. and Winder C. C. A. (1998) Wealth and the demand for money in the European Union, Empirical Economics, 23, 507-24.

Fair, R. C. (1987), "International Evidence on the Demand for Money," Review of Economics and Statistics, 69, 473-80.

Friedman, M. (1988) "Money and the Stock Market" Journal of Political Economy, 96, 221-245

Goldfeld, S. M. (1973), “The Demand for Money Revisited," Brookings Papers on Economic Activity, 3, 577-638.

Goldfeld, S. M. (1976) "The Case of the Missing Money," Brookings Papers on Economic Activity, 3, 683-730.

Goldfeld, S. and D. Sichel (1990), "The Demand for Money," in Handbook of Monetary Economics, by B. M. Friedman and F. H. Hahn, Eds., Volume 1, North-Holland, Amsterdam.

Gordon, R. J. (1984), “The Short-Run Demand for Money: A Reconsideration,” Journal of Money, Credit, and Banking, 16, 
Part 1, 403-434.

Greene, W. H. (2003), Econometric Analysis, fifth edition, Prentice Hall, Upper Saddle River, New Jersey.

Hafer, R. W. and D. W. Jansen (1991), "The Demand for Money in the United States: Evidence from Cointegration Tests," Journal of Money, Credit, and Banking, 23, 155-168.

Hetzel, R. L. and Y. P. Mehra (1989), "The Behavior of Money Demand in the 1980s," Journal of Money, Credit, and Banking, 21, 455-463.

Hsing, Y. (2006), "The Roles of the Exchange Rate and the Foreign Interest Rate in Estonia's Money Demand Function and Policy Implications," Applied Financial Economics Letters, forthcoming.

Hsing, Y. and H. S. Chang (2003) "Testing the Portfolio Theory of Money Demand in the United States" Economia Internazionale/International Economics, 56, 13-22.

Judd, J. L. and J. L. Scadding (1982), "The Search for a Stable Money Demand Function: A Survey of the Post-1973 Literature," Journal of Economic Literature, 20, 93-1023.

Kruszka, M. (2003), "The Demand for Cash in Countries under Transition: A Cointegration Approach,” VIII Conference of Young Economists Unification of European Economies: Opportunities and Threats, 22-24 IX, 201-211.

Laidler, D. (1990), The Demand for Money: Theories, Evidence, and Problems, 3rd edition, HarperCollins, New York.

Marquez, J. (1987), "Money Demand in Open Economies: A Currency Substitution Model for Venezuela," Journal of International Money and Finance, 6, 167-178.

McKinnon, R. (1982), "Currency Substitution and Instability in the World Dollar Standard," American Economic Review, 68, 428-437.

Mehra, Y. P. (1993), "The Stability of the M2 Demand Function: Evidence from an Error-Correction Model," Journal of Money, Credit, and Banking, 25, 455-60.

Mehra, Y. P. (1997), "A Review of the Recent Behavior of M2 Demand," Federal Reserve Bank of Richmond Economic Quarterly, 83, 27-43.

Newey, W. K. and K. D. West (1987), "A Simple, Positive Semi-Definite, Heteroskedasticity and Autocorrelation Consistent Covariance Matrix," Econometrica, 55, 703-708.

Phylaktis, K. and M. P. Taylor (1993), "Money Demand, the Cagan Model and the Inflation Tax: Some Latin American Evidence," Review of Economics and Statistics, 75, 32-37.

Reimers, H.-E. (2004), "Panel Estimates of a Long-Run money Demand Function of the EU Candidates," discussion paper, University of Technique, Germany, 1-17.

Romer, D. (2006), Advanced Macroeconomics, third edition, McGraw-Hill, New York.
Rusek, A. (2001). "The Role and Impact of Monetary Policy in CEFTA Countries," International Advances in Economic Research, 7, 83-90.

Seaks, T. G. and S. K. Layson (1983) "Box-Cox Estimation with Standard Econometric Problems" Review of Economics and Statistics, 65, 160-164.

Small, D. H. and R. D. Porter (1989), "Understanding the Behavior of M2 and V2," Federal Reserve Bulletin, 75, 244254.

Taylor, M. P. (1991), “The Hyperinflation Model of Money Demand Revisited," Journal of Money, Credit \& Banking, Part $1,23,327-351$.

Tobin, J. (1958), "Liquidity Preference as Behavior toward Risk," Review of Economic Studies, 25, 65-86.

Van Aarle, B. and N. Budina (1996), "Currency Substitution and Seignorage in Eastern Europe," Journal of Policy Reform, 1, 279-298. 